\title{
Tragizm komiczny. $O$ niektórych aspektach techniki dramatycznej w utworach Piotra Krasuskiego Daniel i Alzyra
}

Piotr Pirecki 
nAPTS Seria XIV 2008

\section{Piotr Pirecki}

\section{Tragizm komiczny. $O$ niektórych aspektach techniki dramatycznej w utworach Piotra Krasuskiego Daniel i Alzyra}

$\mathrm{B}$ adacz dawnej literatury zawsze staje przed zadaniem rozwiązania zagadek, które powstały w związku z twórczością pisarza mało znanego bądź sprawiającego spore trudności interpretacyjne. Tak dzieje się w przypadku Piotra Krasuskiego, profesora podolinieckiego kolegium pijarskiego, autora siedmiu tragedii, spośród których do dzisiaj zachowały się zaledwie cztery ${ }^{1}$. Dwie z nich są przedmiotem naszej refleksji - Daniel i Alzyra. Stanowią udane przykłady synkretyzmu dramatycznego, pozwalające na utrzymanie zasad klasycystycznego decorum przy równoczesnym rozluźnieniu szyku obu dzieł poprzez wprowadzanie akcentów komicznych. Zgodnie z nauczaniem sztuki wymowy w szkołach pijarskich, niejako z góry podporządkowanych praktycznej stronie prezentacji dzieła tragicznego na scenie, przyjęto jako obowiązujące wzorce zasady wyłożone przez Erazma w Ecclesiastes sive de concionandi ratione libri $I V \mathrm{z} 1553$ roku. Dzieło co prawda dotyczy kaznodziejstwa, ale w księdze IV Erazm dokładniej przedstawił pojęcie actio jako działanie znamionujące doskonałego mówcę, które odnosiło się również do wydarzeń przedstawianych na scenie ${ }^{2}$. Trudno jednoznacznie powiedzieć, na ile znajomość pism Rotterdamczyka ukształtowała pijarską wiedzę o poezji, pewne jest natomiast, że przemyślenia uczonego znalazły praktyczną realizację w życiu szkol-

\footnotetext{
${ }^{1}$ Na temat dramaturgicznej działalności Piotra Krasuskiego pisałem w licznych publikacjach, przedstawiając w nich również aktualny stan badań oraz postulat jak najszybszego wydania pozostawionych w rękopisie tekstów (por. P. Pirecki, Antynomia młodość — starość na podstawie dramatów Piotra Krasuskiego „Daniel” i „Alzyra”, „Acta Universitatis Lodziensis. Folia Litteraria Polonica 9”, Łódź 2007, s. 77-89).

2 Zob. Erasmus Roterodamus, Opera omnia, V-4: Ecclesiasstes Libri I-II; V-5: Libri III-IV, ed. J. Chomarat, Amsterdam 1991, s. 349 (Libri IV).
} 
nej sceny, w dążności do pogodzenia oprawy elokucyjnej wystawianych dzieł właśnie z działaniem teatralnym. Zatem poezja, a w szerszym znaczeniu i sztuka sceniczna (pod którą rozumiano wówczas deklamacje, umiejętność sprawnego wygłaszania oracji oraz grę aktorską) stała się narzędziem praktycznego nauczania, zgodnie zresztą z programem przyjętym wcześniej przez jezuitów ${ }^{3}$. W działalności szkół pijarskich wyróżnić można dwa etapy: pierwszy od powołania do życia pijarskiej sceny, zakończony próbami racjonalistycznych reform $\mathrm{w}$ duchu oświeceniowej doktryny klasycyzmu; oraz drugi, podążający tym właśnie torem, który został rozpoczęty przez Stanisława Konarskiego (1744) i trwał bez mała blisko czterdzieści lat. To właśnie czas efektywnej pracy literackiej Piotra Krasuskiego, głównie w latach pięćdziesiątych osiemnastego stulecia, który zaowocował wystawieniem w Podolińcu wszystkich znanych nam dzisiaj dzieł uczonego profesora ${ }^{4}$. Ze względu na ograniczenia przestrzeni scenicznej, Krasuski musiał pragmatycznie gospodarować środkami komunikacji teatralnej. Stąd pewnego rodzaju, łatwo dająca się wytłumaczyć skłonność do skrótu, wynikająca głównie z poszanowania dla tradycji szkoły w Podolińcu, której program szkolny zakładal, że każdy z uczniów musiał publicznie zaprezentować swoje kwalifikacje oratorskie oraz aktorskie ${ }^{5}$.

Lapidarność dykcji dramatycznej podyktowana była jeszcze innym ograniczeniem, wynikającym z obowiązującej estetyki oraz nazbyt wątłej wyobraźni teatralnej Krasuskiego. Wiadomo, że wszystkie dramaty wystawiane przez wykładowcę pijarskiego kolegium były adaptacjami, że Krasuski wiernie podążał śladem wytyczonym przez pisarzy, których thumaczył - Woltera (Alzyra) oraz ks. Gabriela Le Jaya $(\text { Daniel })^{6}$. Uważniejsza lektura obu tragedii skłania do przypuszczenia, że polski adaptator wytycza jednak nowe szlaki. Antyk jest dla niego doskonałością samą w sobie, niedościgłym wzorem. Jako jeden z pierwszych polskich pisarzy zrozumiał specyfikę osiemnastowiecznych adaptacji, notabene inspirowaną podobnymi działaniami w dobie renesansu i nieco później we Francji ${ }^{77}$. Polski poeta zastosował się więc do zaleceń Mikołaja Boileau, który w poemacie dydaktycznym Sztuka poetycka (1674) sformułował kilka zasad obowiązujących metodologię literackich tłumaczeń,

\footnotetext{
${ }^{3}$ Por. M. Mieszek, Intermedium polskie XVI-XVIII w. Sceny szkolne, Kraków 2007, s. 82-90.

${ }^{4}$ To bardzo charakterystyczne, że na marginesach rękopisów są notatki inscenizacyjne dotyczące gry aktorskiej (por. np. tragedię Alzyra, mikrofilm BUモ sygn. MF 564).

${ }^{5}$ Zob. M. Gostkiewicz, Trzy wieki kolegium podolinieckiego (1642-1942), „Nasza Przeszłość” 1962, t. 15 , s. 90 i nast.).

${ }^{6}$ Więcej na ten temat w rozprawie Stanisława Pigonia (Le Jay w Polsce. Z dziejów dramatu szkolnego $w$ XVIII $w^{\prime}$., „Sprawozdania z czynności i posiedzeń PAN w Krakowie”, R. 50: 1949, s. 36-39).

7 Teresa Kostkiewiczowa pisała: „w Polsce pojawienie się tendencji klasycystycznych wyprzedziło program oświeceniowy. W formowaniu klasycyzmu polskiego istotne znaczenie miało programowe nawiązywanie do nurtów narodowej tradycji o charakterze preklasycystycznym, a więc przede wszystkim do renesansu i do teatru jezuitów z XVII w." (por. T. Kostkiewiczowa, Klasycyzm, sentymentalizm, rokoko. Szkice o prądach literackich polskiego Ośuiecenia, Warszawa 1978, s. 37).
} 
zgodnie z klasycystyczną doktryną piękna. Odejście od praktyki naśladowczej antyku, zwłaszcza rzymskiego, nie było odwróceniem się od estetyki dawnej literatury, lecz powielaniem jej w nowym kształcie, poprzez swoistą reinterpretację, widoczną już w dobie renesansu, a zdecydowanie bardziej rozwiniętą w okresie późnego baroku oraz w początkach XVIII wieku. Godnymi naśladowania stali się pisarze i twórcy „aktualni”, współcześni, a nie przeszli. Tacy, których niemal można było dotknąć, a ich twórczość dobrze poznać oraz przeżyć. Estetyka francuskiego klasycyzmu była na tyle inspirująca, że wydała dojrzałe owoce w postaci literackich naśladowców, i to w całej kulturalnej Europie. Piotr Krasuski również uległ fascynacji doktryną klasycystyczną i zastosował ją na polu najczęściej przez literatów eksploatowanym $\mathrm{w}$ dziedzinie tragedii. $\mathrm{Z}$ dwóch przynajmniej względów stał się jej admiratorem: jako wykładowca retoryki i poetyki sięgnął po wzorzec mu najbliższy, jakim była tragedia o proweniencji klasycystycznej, wprowadzająca do polskiej literatury twórców dotychczas nieznanych bądź prawie nieznanych - księdza jezuitę Le Jaya, przedstawiciela tzw. jezuickiego klasycyzmu, autora tragedii Daniel oraz Woltera, twórcę nurtu zwanego moralistycznym (Alzyra).

Jednak pomimo ścisłego przestrzegania klasycystycznych regul, Krasuski gdzieniegdzie pozwolił sobie na rozluźnienie więzi z konwencjami dramatu regularnego, co zaowocowało włączeniem w estetykę tragedii pierwiastków pozornie jej obcych, za jakie wypadałoby uznać dość liczne akcenty komediowe. Dramaturg postępował więc w zgodzie z zasadami przyjętymi w pijarskiej dydaktyce, która podobnie jak jezuicka, poszukiwała własnych sposobów teatralnej komunikacji z publicznością, licząc na fascynację młodzieży literaturą i sceną. Niemal od samego początku XVIII wieku w kolegiach pijarskich wzrosło zainteresowanie prezentacją scenek mimiczno-ruchowych o zabarwieniu komicznym, będących naturalnym uzupełnieniem widowisk tragicznych. Nie oznacza to wcale, że poszukiwano jakiejś nowej formuly teatru — przecież pijarzy zaledwie udoskonalali program wychowawczy jezuitów, któremu nadawali nowy kształt. Już od połowy XVII wieku przejmują jezuicki schemat sztuk zapustnych, dodatkowo wyposażając je w konwencje panegiryczne, wygłaszane $\mathrm{w}$ celu powitania gości zapraszanych na uczniowskie występy ${ }^{8}$. Okazuje się, że sztuki zapustne jezuitów były znakomitą inspiracją — dzięki nim właśnie pijarzy potrafili stworzyć własny język dykcji artystycznej, umieli odejść od normatywnych zaleceń dla poezji tylko po to, aby zadziwić kunsztem literackiego opisu, w którym znalazło się i miejsce dla sytuacji komicznych. Paradoksalnie, umiejętności teatralne pijarów wcale nie były na rękę prowincjałom zakonnym, głoszącym potrzebę uczczenia chwały Bożej poprzez organizowanie starannie dopracowanych akademii, przy jednoczesnej rezygnacji z widowisk

\footnotetext{
${ }^{8}$ Por. J. Okoń, Barokou'y dramat i teatr szkolny. Wśród zadań publicznych i religijnych, w: idem, Na scenach jezuickich w' dau'nej Polsce (rodzimość i europejskoś́), Warszawa 2006, s. 95.
} 
teatralnych ${ }^{9}$. Na szczęście prefekci szkół oraz rektorzy kolegiów niewiele robili sobie z zaleceń władz, wychodząc ze słusznego założenia, że sami mają najwięcej do powiedzenia w sprawie nauki i wychowania młodzieży. Być może pewien opór wobec władz zakonnych przyspieszył decyzję dotyczącą zaleceń normatywnych dla teatru, w tym wypadku kojarzenia sprzeczności formalnych (tragizmu i komizmu), co było tylko dalekim echem barokowej estetyki, bardziej zaś wiązało się z oczekiwaniami pijarskiej publiczności.

Tym oczekiwaniom Krasuski wyszedł naprzeciw. Osnową wszelkich zmian w dziedzinie rozwiązań formalnych stało się podjęcie dyskursu z obowiązującą zarówno u jezuitów, jak i u pijarów kategorią cudowności, jako zagadnieniem fundamentalnym dla dramatu religijnego, opartego na moralistycznych wzorcach. Maciej Kazimierz Sarbiewski traktował cudowność jako jedną z trzech głównych zalet tragedii. Uważał, że zadaniem, przed którym stają pisarze, jest przezwyciężanie sprzeczności pomiędzy cudownością a prawdopodobieństwem. Wiadomo bowiem, jak bardzo trudno uwierzyć odbiorcy w ogólną sprawność postaci dramatycznej wyrażoną niewytłumaczalnym dla przeciętnego widza bohaterstwem. Sarbiewski tę sprzeczność, jak się okazuje tylko pozorną, rozstrzyga jednoznacznie:

sama trudność w podjęciu czynności bohaterskiej jest podstawą efektownych możliwości. Jeśli bowiem jakaś czynność dochodzi do skutku, mimo że sama przez się jest trudna i z zewnątrz napotyka na przeszkody, to muszą zachodzić nadzwyczajne przyczyny, wspierające tę czynność ze względu na jej wewnętrzną trudność, usuwające zaś to, co jej stoi na przeszkodzie ${ }^{10}$.

Stanowisko Sarbiewskiego bylo fundamentem akcji dramatycznej w obu sztukach. Stwarzało ono dodatkową możliwość wprowadzania w przestrzeń fabularną utworów rozwiązań eklektycznych, pozwalających na włączanie w tragiczną perspektywę akcji zalążków komediowych.

Dramat religijny uczynił więc z cudowności jeden z podstawowych wyznaczników akcji. Krasuski w Danielu wskazał drogę dorastania do świętości głównego bohatera. Trzeba przy tym zaznaczyć, że nie obyła się bez zakrętów i zawirowań, zbaczania z głównego szlaku, jakim były wyznaczone Starym Testamentem dzieje przedstawiciela judejskiej rodziny królewskiej. Daniel nie zachował biblijnej godności króla, w tragedii był pokazany jako zwykły dworzanin, który dzięki mądrości i sprytowi doszedł do licz-

\footnotetext{
${ }^{9}$ Zob. J. Buba, Polskie misterium pasyjne na Spiszu w połowie XVII wieku, „Pamiętnik Teatralny”, R. 25: 1976, z. 1-2, s. 67-68.

${ }^{10}$ M. K. Sarbiewski, O poezji doskonałej czyli Wergiliusz i Homer, tt. M. Plezia, opr. S. Skimina, Wrocław 1954 (BPP B 5), s. 93.
} 
nych zaszczytów. Rozluźnienie więzi z dawnym poglądem, głoszącym potrzebę opiewania w tragedii osób wysokiego rodu bądź stanu, było symptomem zmian zachodzących w osiemnastowiecznym dramacie. Polscy teoretycy poezji w XVIII wieku, zgodnie z literą francuskiego klasycyzmu, głosili postulat upodmiotowienia „zwyklego człowieka”, który jednak musiał odznaczać się niezwykłymi przymiotami ducha i ciała:

\section{Charakter bohaterom naznacz przyzwoity \\ Między pierwsze wyniosłość duszy kładź zaszczyty ${ }^{11}$.}

Krasuski nieco wyprzedzał normatywne założenia klasycystycznej poezji w części odnoszącej się do tragedii. Nie dość, że postępował dowolnie z historycznymi faktami, które oczywiście uległy koniecznej w takich wypadkach mitologizacji, to jeszcze w ramy dzieła tragicznego posiadającego stricte klasycystyczną kompozycję wprowadził elementy jej obce. Na pierwszym planie figurowały wszelkie „drobiazgi” komiczne, układające się w szereg finezyjnie splecionych ze sobą ornamentów słownych, które całej akcji nadawały spoistości i w konsekwencji doprowadziły ją do szczęśliwego zakończenia, a więc zupełnie inaczej niż w dramacie regularnym typu arystotelesowskiego. Pierwiastki komiczne były konsekwentnie rozsiane po całym dziele, poukrywane zręcznie wśród poważnych treści. W pierwszym akcie, niemal na samym początku, Jozedek zarzuca Danielowi brak poczucia humoru i nazbyt poważne podejście do życia. Sam zaś prezentuje postawę odwrotną — w ekspozycji jego słowa brzmią jak wyrzut skierowany do przyjaciela:

\section{JOZEDEK}

Cóż to jest, Danielu, że kiedy wesoło

Masz swe wypogodzone prezentować czoło [...]

Teraz, teraz, i owszem, weselić się trzeba,

Gdy sprzyjają we wszystkim szczodrobliwe nieba [akt I, w. 1-2, 7-8 $]^{12}$.

Jozedek chce rozweselić smutnego Daniela, przed którym piętrzą się same kłopoty, stymulowane prowidencjonalizmem usytuowanym w teraźniejszości i przyszłości, paralelnymi względem siebie ${ }^{13}$. Otwarte głoszenie czci i uwielbienia dla Boga wywołało

${ }^{11}$ F. S. Dmochowski, Sztuka rymotwórcza, oprac. S. Pietraszko, Wrocław 1956 (BN I 158) - Pieśn III, w. 256-257.

12 Tragedia Daniel Piotra Krasuskiego zachowała się w trzech odpisach. Cytaty pochodzą z mikrofilmów sporządzonych przez Profesora Jerzego Starnawskiego oraz z rękopisów zachowanych w zbiorach Maticy Slovenskiej w Martinie, odbitych specjalnie dla zbiorów Uniwersytetu Łódzkiego (pod sygnaturą $\mathrm{mfm} 569$ ).

${ }^{13}$ Ten sam problem tragizmu bohatera jednej z tragedii Franciszka Wężyka zasygnalizował Janusz K. Goliński (Franciszka Wężyka dwugtos o tragedii. „Gliniski” w kregu neoklasycystycznej poezji dramatycznej, w: Problemy tragedii i tragizmu. Studia i szkice, red. H. Krukowska, J. Ławski, Białystok 2005, s. 283-284). 
reperkusje ze strony babilońskiego władcy Dariusza: uwięzienie Daniela i skazanie go na okrutną śmierć spowodowaną pożarciem przez lwy, a następnie cudowne ocalenie wywołane cofnięciem niesprawiedliwego edyktu. Pierwsza obserwacja skłania do zgoła pesymistycznych wniosków - gdzie tu komizm, skoro przytoczone fakty oraz streszczenie dramatu jednoznacznie wskazują na tragiczne uwarunkowania losów głównego bohatera? W tym wlaśnie miejscu ujawnia się subtelność techniki dramatopisarskiej Krasuskiego - akcenty komiczne nie wpływają bezpośrednio na akcję, lecz wspóltworzą zawiązki kontaktów między nadawcą a odbiorcą. To w nich ujawnia się swoista zmysłowość rozwiązań słownych Krasuskiego, w miejscach skądinąd niespodziewanych dla odbiorcy. Usytuowanie w tekście owych komicznych drobiazgów ma na celu wywołanie wesołości, ale zgoła ograniczonej - zwraca się przede wszystkim w stronę predyspozycji psychicznych odbiorcy, który w ciągłym napięciu nie był w stanie śledzić tragicznych losów Daniela. W żadnym razie nie emanuje żywiołowym śmiechem, nawet go nie sugeruje - w zamian Krasuski pokazuje, jak bardzo efektowne może być przekraczanie spodziewanych konwencji, jak łatwo, pisząc tragedię, wyjść poza normy gatunkowe, choćby tylko w szczątkowej postaci. Odbiorca zaś otrzymywał osobliwe katharsis w formie wewnętrznego odprężenia. Mieszanie konwencji, a w zasadzie przekraczanie granic klasycystycznego decorum było pomysłem zaiste makiawelicznym - zaskoczyć widza w miejscu najmniej do tego odpowiednim, a jeszcze zaskoczyć kombinacją tragiczności i komiczności - to już zupełnie przekraczało granice zwykłej wyobraźni.

Dowcip profesora z Podolińca był wyjątkowo delikatnie wycieniowany, prawie że nieuchwytny, a na pewno nie na pierwszy rzut oka. Miał formułę późnobarokowego konceptu, kończącego zawsze daną wypowiedź ironiczną pointą. Do jego wyeksponowania najlepiej nadawał się dialog: napięcia między postaciami kreowały sytuacje zgoła niespodziewane i zaskakujące. I w tym właśnie zaskoczeniu tkwiła nieograniczona potęga poetyckiej wyobraźni, która żywiła się antynomiami. W nich zawarty był oksymoroniczny sens „poważnego dowcipu” podolinieckiego mistrza. Daniel rozpacza z powodu skazania na śmierć i nieopatrznie wydanego edyktu przez Diariusza, zamykając swoje cierpienie w tchnącej dostojeństwem frazie:

Więcej u mnie, wierzaj mi, bojaźń boska, cnota

Waży, niż znikomego pragnienie żywota [w. 53-54].

Po tych słowach otrzymuje od przyjaciela ironiczną ripostę, próbującą obrócić wniwecz istotę wypowiedzianych przez Daniela myśli. Zadziwiająca gra konwencjami poszukiwala środków wyrazu zdolnych przekształcić powagę i patos w chwilowy tylko żart i ironię, jakże zgodną z ożywczą i z popularną w teatrze szkolnym formulą barokowego klasycyzmu, wyrosłego ze szlachetnych założeń ratio studiorum. Odstępstw od reguł w tragedii Krasuskiego było stosunkowo niewiele, a ich semantyczna wartość opierała się na kontaminacji powagi i żartu: 


\section{JOZEDEK}

Prawisz, jako uważam, rzeczy godne śmiechu.

Któż bowiem żyjącego ciągnie cię do grzechu? [w. 55-56]

Żart umiejscowiony w tragedii klasycystycznej nigdy w istocie do końca nie wypełnia sobą aspektów komicznych. Jest tylko jednym $z$ wielu wariantów i jedną $z$ wielu kombinacji rozwiązań poukrywanych w słowach — przybiera zatem kształt quasi-komiczny, dzięki któremu ujawnia się złożoność techniki kontrapunktowej (powaga Daniela nie spotyka należytego wsparcia ze strony Jozedeka, a nawet zostaje zanegowana). Obserwacja artyzmu tragedii skłania do wysnucia wniosku, że gatunek tragedii powstały w szacownych murach szkół pijarskich posiadał dysonansowe rozwiązania poszczególnych konfliktów, że kontrastowe zestawienia stanowiły interesujący chwyt, który umożliwiał bardziej przejrzysty i zrozumiały kontakt $\mathrm{z}$ widownią ${ }^{14}$.

Gdy żart jest niesformalizowany, a więc gdy nie wyraża efektu dramatycznej strategii przyjętej przez autora, niekiedy bywa zaskakującym rozwiązaniem powikłań słownych i bywa pochodną paremiograficznych zabaw, podejmowanych w imię jeszcze późnobarokowego zaskakiwania konceptem ukrytym w pomysłowo skonstruowanej frazie. Gazabar z wyrzutem mówi do Mitrydatesa o nierespektowaniu królewskiego prawa, o braku poszanowania dla władzy. Aby wzmocnić sens swojej wypowiedzi, odwołuje się do potocznego i pejoratywnego zwrotu dotyczącego „niewiernego Żydowina”, którym to mianem obdarzył Daniela:

\section{GAZABAR}

Że wyroków królewskich jak źrzenicy oka Pilnować powinniśmy, że nie ma być zwłoka Dla ich należytego spełnienia? Więc jedna Ma nasze ułożenia psować mucha biedna, Jeden obcy żydowin? Który, czy przez dary Króla sobie omomil, czy przez jakie czary? [w. 409-414].

Na pierwszy rzut oka dysonansowo względem przejrzystej zasady decorum, bezwzględnie przestrzeganej w tragediach, brzmią słowa obraźliwe względem proroka Daniela. Z perspektywy przeciętnego odbiorcy one właśnie wybijają się na plan pierwszy — ale tylko przez chwilę. Bardziej dogłębna analiza tekstu przekonuje jed-

${ }^{14} \mathrm{O}$ „miejscach wspólnych” tragedii powstałych w szkołach pijarskich pisałem w artykule: P. Pirecki, Kształt teatralny „Tragedii Epaminondy” Stanisława Konarskiego. W: Problemy tragedii i tragizmu..., op. cit., s. 67-71. Z przykrością muszę skonstatować, że osiągnięcia dramaturgów pijarskich, jednocześnie nauczycieli, nie były nigdy przedmiotem monograficznej refleksji. A szkoda, z pewnością na taką rozprawę zasługują. 
noznacznie, że na szczególną uwagę zasługuje metonimia „mucha biedna”, posiadająca wiele metaforycznych znaczeń. Odwołuje się do asocjacyjnych skojarzeń, jakże latwo przyswajalnych przez pijarską publiczność - oksymoroniczny frazeologizm „mucha biedna” stanowi z gruntu nieprzyjazną względem proroka definicję jego położenia. Daniel bowiem znalazł się w sytuacji bez wyjścia i w pozycji człowieka pozbawianego szans na obronę - niczym mucha napotkana w miejscu, w którym nigdy nie powinna się znaleźć.

Takich niewątpliwych odstępstw od sztywnych reguł tragedii regularnej było stosunkowo niewiele, jednak miały one w sobie znaczący ładunek treści, wskazując drogę, jaką powinien obrać szkolny dramat. Nie sposób w tym pominąć milczeniem Stanisława Konarskiego i nie wspomnieć o roli, jaką odegral przy reformie nauczania w szkołach pijarskich. Podobnie jak Krasuski, tylko nieco wcześniej, był profesorem retoryki między innymi w podolinieckim kolegium i jednocześnie wykładowcą zaangażowanym w pracę nad kształceniem młodych nauczycieli, naturalnych następców starych kadr. Jak wiele Krasuski zawdzięczał swemu wybitnemu poprzednikowi, najlepiej widać w praktyce - w szkołach następowała stopniowa laicyzacja nauczania oraz coraz wyraźniej postępowała realizacja założeń obywatelskiego wychowania, których zasady wyłożył Konarski między innymi w Tragedii Epaminondy (1756), w której z duchem społecznej edukacji przedstawił koncepcję „szczęśliwego tragizmu”, w oczywisty sposób zbieżną z omawianym dziełem Piotra Krasuskiego ${ }^{15}$.

Radosne zakończenie tragedii Daniel było więc konsekwencją podjętych wysiłków przez reformatorów skupionych wokół światłych nauczycieli, których wysilki nie powiodłyby się, gdyby nie sceniczna praca uczniów i wychowanków. W rezultacie należało oczekiwać, jeszcze przed finałowym rozwiązaniem całego splotu fabularnego, zapowiedzi szczęśliwego zakończenia „krwawej” intrygi. Wrogowie Daniela zostali skazani na okrutną śmierć przez wydanie lwom na pożarcie, zaś prorok ponownie odzyskał zaufanie króla Dariusza wraz z obietnicą współrządzenia Babilonem. Zakładana przez szkolną pragmatykę iluzja szczęśliwego zakończenia w tragedii nie była tylko teoretycznym drogowskazem, za którym należało podążać, ale stała się czynnikiem reformującym normy obowiązujące $w$ dramacie regularnym. Wcale więc, jak błędnie mniemano, nie chodziło o propagowanie znanego już wcześniej gatunku tragikomedii, ale o wprowadzenie do literackiego obiegu zupełnie nowego rodzaju sztuki scenicznej, a taką bez wątpienia była „szczęśliwa tragedia”. Aby nie być gołosłownym, najlepiej odwołać się do końcowej sceny. Żarliwa wiara Dariusza wywołała prawdziwą rewolucję w państwie - lud, widząc wielką ofiarę ponoszoną przez proroka, uwierzył w jedynego Boga i zaczął niszczyć religijne pamiątki politeizmu. Wówczas Daniel wypowiedział niewinną, zdawałoby się, kwestię, ważącą jednak scenicznymi konsekwencjami:

15 Por. M. Klimowicz, Oświecenie, Warszawa 1980, s. 23. 


\section{DANIEL}

Serce rozpływa się z radości na tak piękne dziwa [w. 318].

Niemal identyczny rodzaj przekształceń klasycystycznego tragizmu widać w kolejnej spośród sztuk Piotra Krasuskiego, a mianowicie w Alzyrze. Autor podjął niezwykle wówczas chłonny temat miłości Alzyry do Amora, któremu to związkowi przeciwstawia się okrutny i mściwy Guzman. Akcja rozgrywała się w krainie Potozu w szesnastowiecznym Peru i została okraszona szeregiem awanturniczych perypetii z udziałem najeźdźców hiszpańskich, od czasu wyprawy Kolumba traktujących siebie jako pełnoprawnych władców tych ziem, którymi przyszło rządzić z woli Boga. Punktem kulminacyjnym dość wątłej i nieskomplikowanej intrygi jest pojedynek między rozgoryczonym Zamorem, niemającym nadziei na odzyskanie ukochanej, a Guzmanem, który w trakcie walki przechodzi zadziwiającą metamorfozę — zdawszy sobie sprawę, że Alzyra kocha Zamora, a jednocześnie, nie chcąc być świadkiem ich miłości, dał się pokonać i poniósł śmierć w pojedynku. Tym samym zachował honor i godność człowieka. Zakończenie jest więc optymistyczne, co wynikało z przyjętej przez pijarów koncepcji „szczęśliwego tragizmu” oraz ze szczególnego miejsca, jaką miały dzieje miłości Zamora i Alzyry w dziejach literatury europejskiej, poczynając już od czasów florenckiego renesansu (tę miłosną historię opowiedzial Giovanni Boccaccio w noweli Przytrafienia Saladyna i Torella). Na florenckim mistrzu wzorował się Stanisław Herakliusz Lubomirski: intrygę komedii dworskiej Don Alwares albo Niesforna $w$ miłości kompanija osnuł wokół miłości dwojga zakochanych ${ }^{16}$. Wiele natomiast hipotez łączy się z tragedią Woltera Alzyra, która stanowiła bezpośrednią inspirację dla Krasuskiego. Dogłębna analiza poszczególnych fragmentów obu dzieł — Woltera i Lubomirskiego - dowodzi, że bliski wydaje się pogląd, jakoby Wolter dobrze znal polską komedię i czerpał z niej niejedną inspirację (niemal ta sama akcja i niemal te same postacie, różnice tkwiły w szczegółach: u Lubomirskiego mąż ginie bez wieści i przynaglana przez opiekuna Antonina oddaje rękę innemu, z kolei u Woltera narzeczony nie wraca z wojny i za namową ojca Alzyra wychodzi za Hiszpana. Wszystkie komplikacje rozwiązują się w ostatniej scenie, gdy uznani za zaginionych mąż i narzeczony powracają w tym samym dniu ślubu oblubienic, szczęśliwie zamykając całą akcję). Zwraca uwagę łatwość, z jaką komicznie podjęty przez Boccaccia temat był transponowany na wiele gatunków literackich i jak zadziwiające przybierał kształty, pomimo podobieństwa od komedii do tragedii. Na dobrą sprawę nie powinno to dziwić, skoro problematyka szczęśliwej miłości była jednym ze znamion europejskiego klasycyzmu.

\footnotetext{
${ }^{16}$ Wiele uwag komedii Lubomirskiego poświęcił Stanisław Windakiewicz (Teatr polski przed powstaniem sceny narodowej, Kraków 1925, s. 47). Badacz wysnuł hipotezę, zresztą żywą do dzisiaj, że być może pierwowzorem polskiej sztuki było dzieło nieznanego nam autora.
} 
Nowa i w pełni oryginalna koncepcja tragizmu miała swoje źródło w podjętych przez Krasuskiego interakcyjnych zabawach słowem i ze słowem, nie burzących pierwotnej dla klasycystycznej tragedii zasady decorum. Jedynie i aż wprowadzała ją w nową przestrzeń i nowy wymiar perspektywy teatralnej. Literalnie odczytywane akcenty komediowe w Alzyrze są na dobrą sprawę mało wyraziste i prawie niezauważalne. Dopiero złożenie wymowy całej sceny pozwala na wysnucie wniosku, że Krasuski świetnie rozumie specyfikę tragedii jako dzieła literackiego i teatru, rozumianego jako forma scenicznej prezentacji. Guzman - antagonista pozytywnego Zamora w długiej przemowie do ojca daje wyraz swej niechęci do peruwiańskiej ludności tubylczej. Wówczas pozwala sobie na obraźliwe sformułowania względem ludu. W jego mniemaniu stwierdzenia świadczące o pogardzie dla drugiego człowieka są przejawem dobrego humoru i zdolności krasomówczych. Świadectw braku sympatii do podbitej ludności jest wiele: autochton zaprezentowany w ramach genus deliberativum posiada nieludzkie wymiary, jest określany mianem monstrum, bez wymiernego kształtu ani odpowiedniego prestiżu. Nie dziwi więc cały ciąg negatywnych sformułowań, które dla pijarskiej publiczności miały zabawną postać. Każdy „Amerykanin” jest „hardy”, a w swej niewoli „zgrzyta, miota się i syka” (w. 79). W najgorszym razie „smrodem zalatuje i pierdzi”, co w ostatecznym rozrachunku przyczynia się do zdeprecjonowania tubylców (w. 80-81). Nawet Alwares przyznal, że prawdziwi „grubijanie” to hiszpańscy okupanci, z którymi pod względem okrucieństwa nikt nie może się mierzyć. Prawdopodobnie rozluźnienie szyku składniowego, służącego budowaniu akcji w tragedii, miało wartość perswazyjną, bowiem należało wyrobić u odbiorcy poczucie obecności w nieznanym świecie dalekiego Peru, a rzecz całą uprawdopodobnić poprzez wyeksponowanie nędzy życia prostego ludu w dalekiej krainie mitycznego Potozu. Włączenie w ramy tragedii sformułowań nielicujących z godnością wysokiego stylu gatunków regularnych, zrodzonych $\mathrm{z}$ arystotelesowskiego ducha, nasycone było komiczną spektakularnością, dzięki której sens sztuki stawał się latwiej przyswajalny, zaś młódź miała okazję do śmiechu i zabawy. Nawet w formie tak niewybrednej jak grubiańskie słowa kierowane wprost do amerykańskiego ludu. Ów akcent komiczny, osobliwy w tragediach, mial plebejską proweniencję - wiadomo przecież, że widowiska wystawiane na scenie pijarskiej posiadały niekiedy zabawne rozwiązania sytuacji dramatycznych, czego najczęstszym przejawem były jasełka i komiczne intermedia, posługujące się niewyszukanym żartem $^{17}$. Po sprawdzeniu zawartości wolteriańskiego pierwowzoru trzeba bezdyskusyjnie stwierdzić, że francuski pisarz nie pozwalał sobie na tak niesformalizowane „swawole”, przeciwstawiające się tragicznej konwencji, nawet w tak wąskim wymiarze jak zaledwie kilka zapisanych wersów. Niewątpliwie Krasuski uczynił ukłon w stronę odbiorcy aby zachęcić uczniów do oglądania skądinąd niełatwej przecież sztuki, musiał sięgnąć 
do arsenałów środków językowych, które cieszyłyby młodzież swoją prostotą i frazeologicznym nieskomplikowaniem.

To nie jedyny sposób formulowania dowcipu. Niekiedy ma on wymiar znacznie bardziej wysublimowany, wręcz artystycznie nowatorski, gdyby przyjąć, że zabawy słowne oparte na metaforycznych skojarzeniach, skladające się z oksymoronów, w istocie wypełnione są żartem. Montez, władca Peru, odrzuca pogański zabobon pod wpływem hiszpańskich perswazji i poniekąd deklaruje przywiązanie do katolicyzmu. Swoje stanowisko przedstawia bez natrętnego moralizatorstwa i patosu, za to z rzadko spotykanym humorem i lekkością:

Tak jest, nie inaczej uznałem fałsz szczery

Wiary tej, porzucilem jej głupie chimery [w. 249-250].

Oksymoroniczny „fałsz szczery” opiera się na paradoksie wiary jako przyczyny powstawania "głupich chimer”. Paradoksie, bowiem fakt odrzucenia pogańskich bożków oznacza równocześnie wyznanie chrześcijańskiego systemu wartości. Podobny rodzaj stylistycznej dysharmonii, zawierającej pierwiastek żartu o zdecydowanie pejoratywnym wydźwięku, widać w kolejnym fragmencie dzieła. Guzman potraktował Alzyrę wielce niepochlebnie, wyrażając się o zakochanej w Zamorze kobiecie z wyraźną dezaprobatą:

Twymi go łzami wskrzeszasz, poprzestań go kochać, Cholerę wzbudzasz we mnie, niechaj dłużej szlochać Nad nim [...] [w. 298-300].

Komiczna wymowa niektórych scen nie ma związku z kompozycją obu tragedii ${ }^{18}$. W zasadniczym stopniu nie wpływa na przebieg akcji, ani też na intrygę czy sytuacje konfliktowe. Jedynie ukrywa się w słowach: słowie pojedynczym bądź w całej frazie wersyfikacyjnej i zawsze posiada wartość naddaną, metaforyczną. To komiczność warta wyszczególnienia, dla niej przecież Krasuski odszedł od „czystej formy” tragedii, w końcu dla niezbyt wyszukanej, prostej komiczności podjął ryzyko konfrontacji ze szkolną publicznością, która przecież nie zawsze odpowiednio rozumiała intencje pijarskich autorów. Krasuski nie zrezygnował z obowiązujących konwencji, lecz wzbogacił je pierwiastkami dotąd nieznanymi polskiej literaturze, które przyczyniły się do powstania zupełnie nowego gatunku — tragedii o szczęśliwym zakończeniu ${ }^{19}$.

18 Zob. A. Okopień-Sławińska, Semantyka uypouiedzi poetyckiej. (Preliminaria), Kraków 2001, s. 117118. Co prawda, uczona nie wypowiada się w tym miejscu o tragedii jako gatunku, ale zwraca uwagę na uniwersalny sens słów poetyckich, wymagających rekonstrukcji zgodnie z intencją autora.

${ }^{19}$ Szczęśliwe zakończenie tragedii to znamię sztuk oświeceniowych o proweniencji szkolnej. Widowiska skonstruowane zgodnie z zasadą szczęśliwego zakończenia odchodziły wprawdzie od sztywnych schematów normatywnych poetyk (Pontanus, Sarbiewski, Boileau), ale wywoływały zachwyt publiczności. 